\title{
Asymptomatic intrapetrous carotid artery stenosis after a gunshot to the head
}

Alessandro De Benedictis, MD, PhD, Giovanna Stefania Colafati, MD, Alessia Carboni, MD, Andrea Carai, MD, PhD, and Carlo Efisio Marras, MD

Neurology ${ }^{\circledR}$ 2020;95:1057-1058. doi:10.1212/WNL.0000000000011055

Figure Imaging

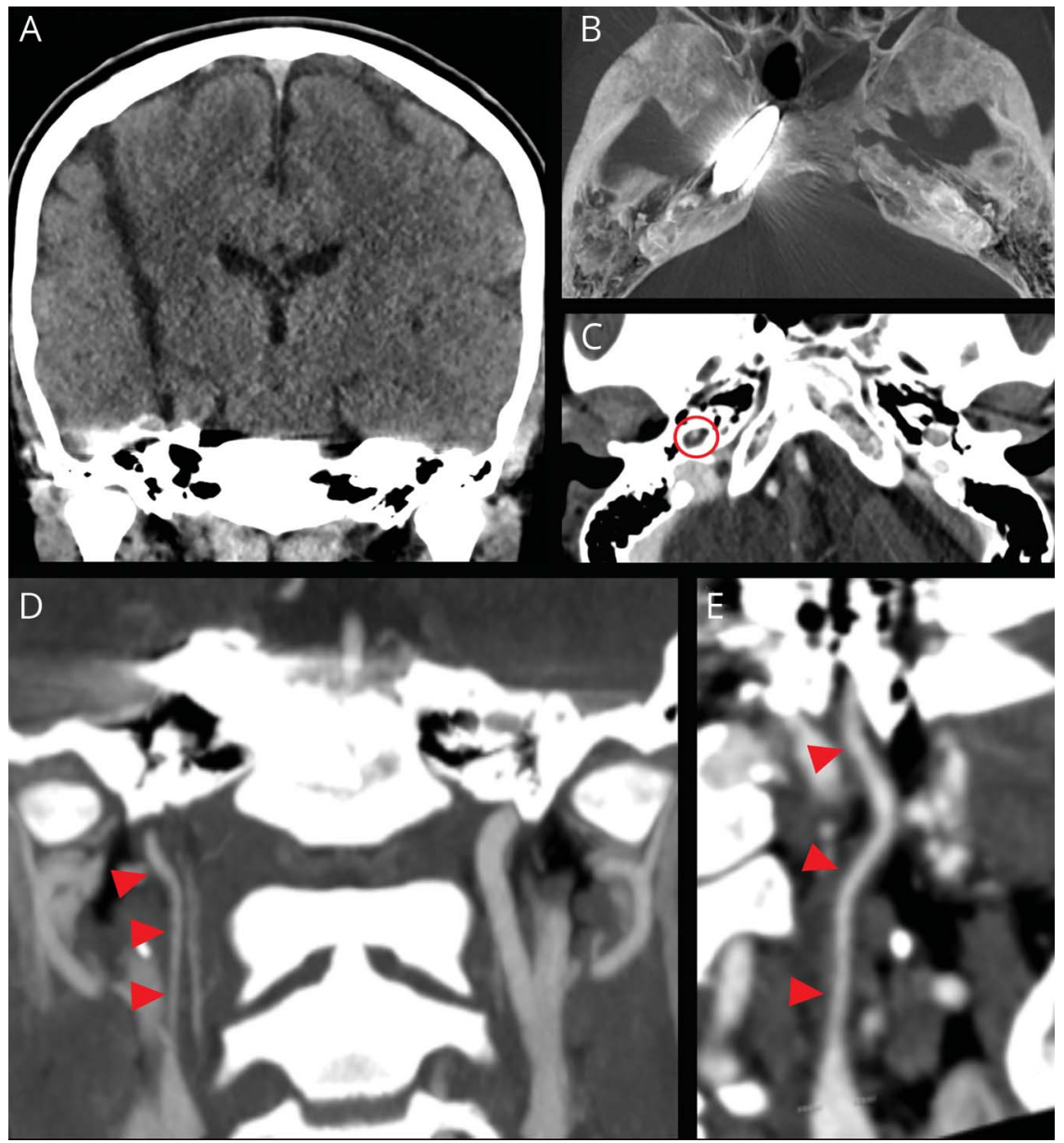

Standard CT shows a coronal view of bullet's intracranial trajectory (A); maximum intensity projection CT shows the bullet retained intracranially within the right petrous apex (B); axial (C), coronal (D), and sagittal (E) view of CT angiography demonstrate the narrowed concentric lumen of the intrapetrous (C, red circle), and cervical (D, E, red arrowheads) tracts of the right internal carotid artery, consistent with dissection.

An 11-year-old girl was accidently hit by a gunshot. Immediately after the injury, she developed a transient headache, vomiting, and a reduced level of consciousness. The neurologic examination was otherwise normal. A cerebral CT angiography showed the parenchymal course of the bullet from the right parietal region to the right petrous apex, without bleeding. The cervical, intrapetrous, and intracavernous segments of the internal carotid artery showed a residual concentric
Correspondence

Dr. De Benedictis

alessandro.debenedictis@

opbg.net
MORE ONLINE

○ Video

From the Neurosurgery Unit (A.D.B., A. Carai, C.E.M.), Department of Neurological and Psychiatric Sciences (A.D.B., A. Carai, C.E.M.), and Neuroradiology Unit (G.S.C., A. Carboni), Imaging Department, Bambino Gesù Children's Hospital, IRCCS, Rome, Italy.

Go to Neurology.org/N for full disclosures. Funding information and disclosures deemed relevant by the authors, if any, are provided at the end of the article. 
lumen of 1-2 mm, indicating a plausible mechanism of posttraumatic dissection, secondary to the energy transference from the bullet to surrounding structures (figure). After 6 months, the patient was neurologically normal. This case shows an exceptional, but potentially lethal event. ${ }^{1,2}$ Three-dimensional neuroradiologic rendering was helpful in evaluating the neurovascular relationships of the bullet (video 1).

\section{Acknowledgment}

The authors thank Aneil Srivastava and Aalap Herur-Raman for their help in video editing and language revision of the manuscript.

\section{Study funding}

No targeted funding reported.

\section{Disclosure}

The authors report no disclosures relevant to the manuscript. Go to Neurology.org/N for full disclosures.

\section{Appendix Authors}

\begin{tabular}{|c|c|c|}
\hline Name & Location & Contributions \\
\hline $\begin{array}{l}\text { Alessandro } \\
\text { De } \\
\text { Benedictis, } \\
\text { MD, PhD }\end{array}$ & $\begin{array}{l}\text { Neurosurgery Unit, } \\
\text { Department of } \\
\text { Neurological and } \\
\text { Psychiatric Sciences, } \\
\text { Bambino Gesù Children's } \\
\text { Hospital, IRCCS, Rome, Italy }\end{array}$ & $\begin{array}{l}\text { Drafting/revision of the } \\
\text { manuscript for content, } \\
\text { including medical writing } \\
\text { for content; major role in } \\
\text { the acquisition of data; } \\
\text { study concept or design; } \\
\text { analysis or interpretation } \\
\text { of data }\end{array}$ \\
\hline
\end{tabular}

Appendix (continued)

\begin{tabular}{|c|c|c|}
\hline Name & Location & Contributions \\
\hline $\begin{array}{l}\text { Giovanna } \\
\text { Stefania } \\
\text { Colafati, MD }\end{array}$ & $\begin{array}{l}\text { Neuroradiology Unit, } \\
\text { Imaging Department, } \\
\text { Bambino Gesù Children's } \\
\text { Hospital, IRCCS, Rome, Italy }\end{array}$ & $\begin{array}{l}\text { Drafting/revision of the } \\
\text { manuscript for content, } \\
\text { including medical writing } \\
\text { for content; major role in } \\
\text { the acquisition of data; } \\
\text { study concept or design; } \\
\text { analysis or interpretation } \\
\text { of data }\end{array}$ \\
\hline $\begin{array}{l}\text { Alessia } \\
\text { Carboni, MD }\end{array}$ & $\begin{array}{l}\text { Neuroradiology Unit, } \\
\text { Imaging Department, } \\
\text { Bambino Gesù Children's } \\
\text { Hospital, IRCCS, Rome, Italy }\end{array}$ & $\begin{array}{l}\text { Drafting/revision of the } \\
\text { manuscript for content, } \\
\text { including medical writing } \\
\text { for content; study concept } \\
\text { or design; analysis or } \\
\text { interpretation of data }\end{array}$ \\
\hline $\begin{array}{l}\text { Andrea } \\
\text { Carai, MD, } \\
\text { PhD }\end{array}$ & $\begin{array}{l}\text { Neurosurgery Unit, } \\
\text { Department of Neurological } \\
\text { and Psychiatric Sciences, } \\
\text { Bambino Gesù Children's } \\
\text { Hospital, IRCCS, Rome, Italy }\end{array}$ & $\begin{array}{l}\text { Drafting/revision of the } \\
\text { manuscript for content, } \\
\text { including medical writing } \\
\text { for content; study concept } \\
\text { or design }\end{array}$ \\
\hline $\begin{array}{l}\text { Carlo Efisio } \\
\text { Marras, MD }\end{array}$ & $\begin{array}{l}\text { Neurosurgery Unit, } \\
\text { Department of Neurological } \\
\text { and Psychiatric Sciences, } \\
\text { Bambino Gesù Children's } \\
\text { Hospital, IRCCS, Rome, Italy }\end{array}$ & $\begin{array}{l}\text { Drafting/revision of the } \\
\text { manuscript for content, } \\
\text { including medical writing } \\
\text { for content; study concept } \\
\text { or design }\end{array}$ \\
\hline
\end{tabular}

\section{References}

1. Abu-Judeh HH, Abdel-Dayem HM, El-Zeftawy H, Kumar M. Cerebral perfusion imaging in asymptomatic carotid artery occlusion following gun shot. J Nucl Med 1998;39:629-631.

2. Rammo RA, DeFazio MV, Bullock MR. Management of migrating intracranial bullets: lessons learned from surviving an AK-47 bullet through the lateral brainstem. World Neurosurg 2012;77:591.e19-e24.

\section{AAN Online Learning}

Browse a variety of online CME, self-assessment, and other learning activities to suit your wide-ranging interests and learning styles. Visit AAN.com/Learn.

\section{The AAN is at Your Side}

When you're in the office, the AAN is at your side. The AAN is your \#1 resource to support you and your care team. Whether it's resources to help you and your staff provide the best care for your patients, ensure proper reimbursement, or maximize practice performance, the AAN is at your side. Access these resources today at AAN.com/view/practiceresources. 


\section{Neurology}

\section{Asymptomatic intrapetrous carotid artery stenosis after a gunshot to the head}

Alessandro De Benedictis, Giovanna Stefania Colafati, Alessia Carboni, et al. Neurology 2020;95;1057-1058 Published Online before print October 14, 2020 DOI 10.1212/WNL.0000000000011055

This information is current as of October 14, 2020

\section{Updated Information \&} Services

References

Subspecialty Collections

Permissions \& Licensing

Reprints including high resolution figures, can be found at: http://n.neurology.org/content/95/23/1057.full

This article cites 2 articles, 1 of which you can access for free at: http://n.neurology.org/content/95/23/1057.full\#ref-list-1

This article, along with others on similar topics, appears in the following collection(s):

All Pediatric

http://n.neurology.org/cgi/collection/all_pediatric Brain trauma

http://n.neurology.org/cgi/collection/brain_trauma

Information about reproducing this article in parts (figures,tables) or in its entirety can be found online at:

http://www.neurology.org/about/about_the_journal\#permissions

Information about ordering reprints can be found online:

http://n.neurology.org/subscribers/advertise

Neurology ${ }^{\circledR}$ is the official journal of the American Academy of Neurology. Published continuously since 1951, it is now a weekly with 48 issues per year. Copyright () 2020 American Academy of Neurology. All rights reserved. Print ISSN: 0028-3878. Online ISSN: 1526-632X.

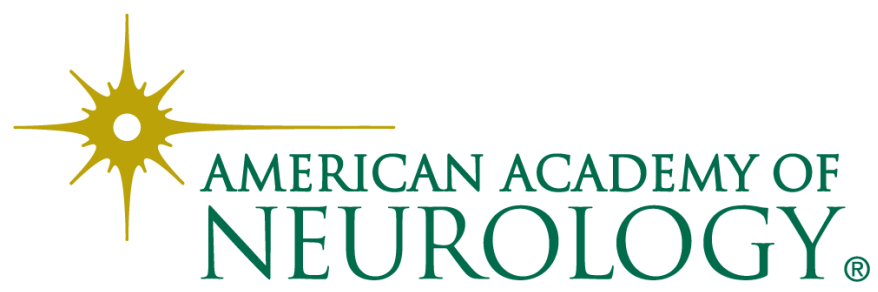

